\title{
Pengaruh Neraca Transaksi Berjalan Terhadap Pertumbuhan Ekonomi Indonesia
}

\author{
oleh: \\ *) Sudirman \\ **)Dosen Tetap Universitas Batanghari Jambi
}

\begin{abstract}
Indonesia is a country with an open economy, which means activities in developing economies are heavily influenced by the foreign sector. The openness of the economy has an impact on a country's balance of payments relating to the flow of trade and capital flows. Various efforts are needed to increase exports in order to increase the Reserves. While the policy on imports directed to protect and develop domestic production. On the other hand domestic funding constraints need to be addressed to maintain fluency in development, so that funds from abroad in the form of loans or assistance that is still very necessary. All of this is intended to maintain the stability of International Balance of Payments (BOP) that prose foreign trade can be sustained. In one there is a structure of balance of payments current account (current account). In theory consists of the balance of current account balance on goods, services account, and unilateral transfers. Positive value or an increase in the current account means there is a current account surplus and vice versa if it is negative or the socalled current account deficit decline.
\end{abstract}

Keywords : trade balance, economic grouth

\section{Latar Belakang Penelitian}

Indonesia merupakan negara yang menganut sistem perekonomian terbuka, yang artinya dalam mengembangkan kegiatan perekonomiannya banyak dipengaruhi oleh sektor luar negeri. Adanya keterbukaan perekonomian ini memiliki dampak pada neraca pembayaran suatu negara yang menyangkut arus perdagangan dan lalu lintas modal. Berbagai upaya untuk meningkatkan ekspor sangat dibutuhkan dalam rangka memperbesar Cadangan Devisa. Sementara kebijaksanaan di bidang impor diarahkan untuk melindungi dan mengembangkan produksi dalam negeri. Di sisi lain keterbatasan dana dalam negeri perlu ditanggulangi untuk menjaga kelancaran dalam pembangunan, sehingga dana dari luar negeri yang berupa pinjaman atau yang bersifat bantuan masih sangat diperlukan. Kesemuanya ini dimaksudkan untuk menjaga kestabilan Neraca Pembayaran Internasional (NPI) sehingga prose perdagangan luar negeri dapat di jaga kelangsungannya.

Di dalam salah satu struktur neraca pembayaran terdapat Neraca Transaksi Berjalan (Current Account). Secara teori Neraca Transaksi berjalan terdiri dari neraca barang, neraca jasa, dan unilateral transfer. Nilai positif atau terjadinya kenaikan pada neraca transaksi 
berjalan berarti terjadi current account surplus dan sebaliknya jika nilainya negatif atau terjadinya penurunan disebut current account deficit.

Tabel 1.1

Neraca Transaksi Berjalan Indonesia 2008 - 2013 (Juta USD)

\begin{tabular}{|c|c|c|c|c|}
\hline Tahun & Barang & Jasa & Unilateral Transfer & Jumlah \\
\hline 2008 & 29.660 & $(9.874)$ & $(8.927)$ & 10.859 \\
\hline 2009 & 32.753 & $(11.841)$ & $(10.421)$ & 10.491 \\
\hline 2010 & 22.916 & $(12.998)$ & $(9792)$ & 126 \\
\hline 2011 & 30.932 & $(9.741)$ & $(10.563)$ & 10.628 \\
\hline 2012 & 30.627 & $(9.323)$ & $(16.160)$ & 5.144 \\
\hline 2013 & 35.348 & $(11.822)$ & $(21.457)$ & 2.069 \\
\hline
\end{tabular}

Sumber : BI (Data Diolah) 2014

Keterangan : ( ) mengalami defisit

Berdasarkan Tabel 1.1 terlihat bahwa Neraca Barang selalu surplus dengan kecenderungan yang meningkat. Namun surplus tersebut tidak mampu membentuk peningkatan yang stabil pada Neraca Transaksi Berjalan. Neraca Transaksi Berjalan dalam periode tersebut mengalami perkembangan yang terus berubah-ubah tiap tahunnya. Hal ini disebabkan Neraca Jasa dan Unilateral Transfer mengalami defisit dari tahun ke tahun daripada surplus Neraca Barang dan cenderung meningkat dari tahun ke tahun. Perkembangan neraca perdagangan, neraca jasa-jasa neto, dan unilateral transfer secara langsung mempengaruhi Neraca Transaksi Berjalan.

Defisit Neraca Transaksi Berjalan ditutup dengan surplus Neraca Modal, terutama dengan modal yang bersifat jangka pendek (portofolio invesment), yang relatif berubah/tidak tetap (fluktuatif). Sehingga, apabila terjadi penarikan dana perbankan secara besar-besaran (rush) akan mengancam posisi Cadangan Devisa negara, akhirnya akan mengakibatkan terjadinya krisis nilai tukar mata uang nasional terhadap Valuta Asing.

Menurut Widiatmoko (1997:18) dampak dari defisit Neraca Transaksi Berjalan begitu luas, beruntun dan saling kait-mengkait. Sejumlah implikasi negatif yang dapat dibawa akibat defisit Neraca Transaksi Berjalan yang besar dan berkepanjangan. Secara kronologis akan mungkin berproses dalam beberapa gejala seperti: perekonomian cenderung mengarah kepada penurunan pendapatan nasional yang berdampak kepada menurunnya tingkat kegiatan ekonomi nasional. Disamping itu juga dapat menyebabkan semakin menipisnya devisa atau cadangan valuta asing yang dimiliki sehingga kurs mata uang cenderung mengalami apresiasi atau mata uang dalam negeri mengalami depresiasi. Keadaan ini lebih lanjut menyebabkan 
harga barang-barang dan jasa-jasa impor menjadi mahal. Padahal banyak industri dalam negeri dan konsumsi masyarakat pada situasi defisit Neraca Transaksi Berjalan sangat tergantung kepada barang-barang dan jasa-jasa impor. Situasi ini selanjutnya menyebabkan inflasi yang tinggi dan berkepanjangan dapat menyebabkan pelarian modal ke luar negeri, sehingga menyebabkan perekonomian dalam negeri tidak dapat berkembang. Untuk mengetahui lebih jelasnya perkembangan Neraca Transaksi Berjalan dan Pertumbuhan Ekonomidi Indonesia dapat dilihat pada tabel 1.2.

Tabel 1.2

Perkembangan Neraca Transaksi Berjalan, PDB, dan Pertumbuhan Ekonomi Di Indonesia periode 2008-2013

\begin{tabular}{|c|c|c|c|c|}
\hline Tahun & $\begin{array}{c}\text { Neraca } \\
\text { Transaksi } \\
\text { Berjalan } \\
\text { (Juta USD) }\end{array}$ & $\begin{array}{c}\text { Perkembangan } \\
\mathbf{( \% )}\end{array}$ & $\begin{array}{c}\text { PDB } \\
\text { (Miliar } \\
\text { Rupiah) }\end{array}$ & $\begin{array}{c}\text { Pertumbuhan } \\
\text { Ekonomi } \\
\mathbf{( \% )}\end{array}$ \\
\hline 2008 & 10.859 & $3.806,12$ & $1.847 .126,7$ & 5,50 \\
\hline 2009 & 10.491 & $(3,39)$ & $1.964 .327,3$ & 6,35 \\
\hline 2010 & 126 & $(98,80)$ & $2.082 .456,1$ & 6,01 \\
\hline 2011 & 10.628 & $8.334,92$ & $2.177 .741,7$ & 4,58 \\
\hline 2012 & 5.144 & $(51,60)$ & $2.310 .689,8$ & 6,10 \\
\hline 2013 & 2.069 & $(59,78)$ & $2.463 .342,0$ & 6,61 \\
\hline
\end{tabular}

Sumber : BPS dan BI (Data Diolah) 2014

Keterangan : () mengalami penurunan

Dari Tabel 1.2 terlihat bahwa sejak tahun 2008 hingga tahun 2013 nilai Neraca Transaksi Berjalan rata-rata berada diantara nilai positif USD 5.000,- juta hingga USD 10.000,- juta. Namun pada tahun 2004 nilai Neraca Transaksi Berjalan turun dibawah nilai positif USD 5.000,- juta. Kemudian pada tahun 2005 dan 2008 nilai Neraca Transaksi Berjalan turun kembali secara drastis dibawah nilai positif USD 500,- juta. Lalu naik lagi mencapai puncak tertinggi pada nilai lebih dari USD 10.000,- juta yaitu pada tahun 2006, 2007, dan 2009. Memasuki tahun 2011 nilainya turun menjadi hanya USD 2.069,- juta.

Sementara itu Pertumbuhan Ekonomi di Indonesia pada periode yang sama nilainya selalu meningkat dan pertumbuhannya tiap kali mengalami peningkatan tiap tahunnya. Yang 
mana peningkatan tertinggi sebesar 6,35\% terjadi pada tahun 2007 dan peningkatan terendah terendah sebesar 4,31\% terjadi pada tahun 2002 .

\section{Perumusan Masalah}

Berdasarkan latar belakang dan identifikasi masalah yang telah di kemukakan diatas, maka dapat dirumuskan masalahnya sebagai berikut:

1. Faktor-faktor apa saja yang paling dominan dalam mempengaruhi perkembangan Neraca Transaksi Berjalan dan Pertumbuhan Ekonomi di Indonesia periode 2008-2013?

2. Berapa besar pengaruh neraca transaksi berjalan terhadap pertumbuhan ekonomi di Indonesia periode 2008-2013?

\section{Metodologi}

Untuk mengetahui pengaruh neraca transaksi berjalan terhadap pertumbuhan ekonomi di Indonesia, digunakan alat analisis regresi linier sederhana dengan data time series. Regresi Linear Sederhana merupakan alata analisis yang di gunaka untuk mengetahui besarnya pengaruh variable bebas (X) terhadap variable terikat (Y) (Danang, 2012:115). Adapun regresi linier sederhana menggunakan model dasar sebagai berikut:

$$
Y=\beta X+\varepsilon
$$

Berdasarkan rumus di atas dapat di Ln kan sebagai berikut:

$$
L \quad Y=\beta L \quad X+\varepsilon
$$

Dimana :

$\mathrm{Y}=$ Variabel tidak bebas (terikat)

$X=$ variabl bebas

$\beta=$ Koefesien Regresi

$\varepsilon=$ error

Adapun yang menjadi alasan menggunakan model analisis logaritma karena analisis logaritma ini mempunyai kelebihan untuk mengetahui nilai koefesien elastisitas dan melinierkan suatu variable non linier.

Untuk mengetahui pengaruh neraca transaksi berjalan terhadap pertumbuhan ekonomi di Indonesia (yang mana dalam memasukan data untuk mengukur pertumbuhan ekonomi di Indonesia menggunakan nilai PDB terhadap harga konstan 200) dapat menggunakan persamaan sebagai berikut:

$$
L \quad Y=\beta L \quad X+\varepsilon
$$


Dimana :

$\mathrm{Y}=$ Pertumbuhan Ekonomi Indonesia

$X=$ Neraca Transaksi Berjalan

$\beta=$ Koefesien Regresi

$\varepsilon=$ error

Uji Hipotesis

Pengujian secara simultan (Uji F)

Untuk menguji secara bersama-sama antara variable bebas dengan variabel terikat dengan melihat tingkat signifikansi (F) pada $\alpha=5 \%$ rumus yang digunakan:

$$
F_{h}=\frac{\frac{R^{2}}{K-1}}{\frac{1-R^{2}}{N-K}}
$$

Keterangan:

$\mathrm{R}$ : koefisien korelasi ganda.

Fh : F hitung.

$\mathrm{K}$ : jumlah variabel bebas.

$\mathrm{N}$ : jumlah sampel yang dipakai.

Pengujian setiap koefisien regresi bersama-sama dikatakan signifikan bila nilai mutlak Fhit $\geq$ Ftabel atau nilai probabilitas signifikansi lebih kecil dari 0,05 (tingkat kepercayaan yang dipilih) maka hipotesis nol (Ho) ditolak dan hipotesis alternatif (Ha) diterima, sebaliknya dikatakan tidak signifikan bila nilai $\mathrm{F}_{\text {hit }}<\mathrm{F}_{\text {tabel }}$ atau nilai probabilitas signifikansi lebih besar dari 0,05 (tingkat kepercayaan yang dipilih) maka hipotesis nol (Ho) diterima dan hipotesis alternatif (Ha) ditolak.

\section{Analisis dan Pembahasan}

Model regresi yang digunakan adalah model regresi dengan variabel Pertumbuhan Ekonomi Indonesia (Y) sebagai variabel dependent (variabel tak bebas) dan tolak ukur dari PDB, dan variabel Neraca Transaksi Berjalan (X) sebagai variabel independet (bebas), dengan fungsi $\mathrm{Y}=\mathrm{f}(\mathrm{X})$, model regresi dalam penelitian ini adalah sebagai berikut :

Rangkuman hasil perhitungan Regresi dengan menggunakan software SPSS versi 16.0 adalah sebagai berikut : 
Tabel :1.3

Rangkuman Hasil Perhitungan Regresi

\begin{tabular}{|c|c|c|c|c|c|c|}
\hline $\begin{array}{l}\text { Variabel } \\
\text { Terikat }\end{array}$ & $\begin{array}{l}\text { Variabel } \\
\text { Bebas }\end{array}$ & $\beta$ & T hitung & $\begin{array}{l}\text { Prob. } \\
\text { Sig }\end{array}$ & $\begin{array}{l}\text { Nilai } \\
\text { VIF }\end{array}$ & $\begin{array}{l}\text { Nilai } \\
\text { Tolerance }\end{array}$ \\
\hline $\begin{array}{l}\text { Pertumbuhan } \\
\text { Ekonomi } \\
\text { Indonesia(Y) }\end{array}$ & $\begin{array}{l}\text { Neraca } \\
\text { Transaksi } \\
\text { Berialan }(\mathrm{X})\end{array}$ & $0.032^{-}$ & $-1,044$ & 0.327 & 1 & 1 \\
\hline $\begin{array}{ll}\mathrm{F} & : 1.089 \\
\mathrm{R}^{2} & : 0.120 \\
\mathrm{~N} & : 10 \\
\text { df } 1 \quad: 1 \\
\text { konstanta }: 2,38\end{array}$ & $\mathrm{df} 2: 8$ & 327 & & & & \\
\hline
\end{tabular}

Berdasarkan Tabel 1.3 maka persamaan regresinya adalah sebagai berikut:

$$
Y=2,389-0,032 X+e
$$

Hasil dari persamaan regresi linear sederhana tersebut memberikan pengertian, yaitu :

a. Dengan nilai $\beta$ sebesar $-0,032$, menunjukkan bahwa setiap ada peningkatan 1USD PDB atau $1 \%$ pertumbuhan ekonomi maka neraca transaksi berjalan akan menurun sebesar 0,032 USD.

b. Dengan nilai $\mathrm{R}^{2}$ yang mempunyai nilai sebesar 0,120 mengandung arti bahwa $12 \%$ dari variabel neraca transaksi berjalan mampu dijelaskan oleh variabel pertumbuhan ekonomi Indonesia melalui PDB dan 88\% di jelaskan oleh variabel lain.

\section{Pengujian Secara Simultan (Uji F)}

Dari Tabel 1.3 di atas secara bersama-sama (uji F) variabel bebas yaitu Neraca Transaksi Berjalan kurang mempunyai pengaruh yang signifikan terhadap variabel Pertumbuhan Ekonomi Indonesia pada tingkat kepercayaan sampai dengan 5\%. Hal ini dapat dilihat nilai Prob.Sign sebesar 0,327 lebih besar dari 0,05 dan nilai $\mathrm{F}$ hitung sebesar 1,089 lebih kecil dari $\mathrm{F}$ tabel $(5,32)$. Dengan demikian maka hipotesis nol (H0) diterima dan hipotesis alternatif (Ha) ditolak atau tidak signifikan, yang artinya bahwa variabel independent kurang mempengaruhi variabel dependen. 


\section{Kesimpulan}

Berdasarkan hasil analisis dan pembahasan yang telah dilakukan, maka dapat ditarik kesimpulan sebagai berikut :

1. Faktor yang paling dominan di dalam perkembangan neraca transaksi berjalan di Indonesia adalah faktor neraca barang, khususnya ekspor non migas.

2. Faktor yang paling dominan di dalam pertumbuhan ekonomi di Indonesia adalah sektor industri pengolahan.

3. Variabel Neraca Transaksi Berjalan tidak berpengaruh signifikan terhadap Pertumbuhan Ekonomi di Indonesia. Hal ini dikarenakan dalam periode 2008 dan 2003 terjadi lonjakan harga minyak dunia dan krisis subprime mortgage di AS dan yang berujung kepada krisis sektor keuangan dan anjloknya pertumbuhan ekonomi global. Krisis subprime mortgage berdampak pada tekanan depresiasi yang tinggi yang dialami oleh nilai tukar rupiah. kuantitas output yang diproduksi maupun tingkat harga. Nilai produk domestic bruto tidak dipengaruhi oleh harga barang-barang.

4. Dari hasil regresi didapat R2 sebesar 0,120 , artinya sekitar $12 \%$ variabel pertumbuhan ekonomi dapat dijelaskan oleh variabel bebas (Neraca Transaksi Berjalan), dan sekitar 88 $\%$ dijelaskan variabel lain di luar model.

5. Surplus pada neraca barang lebih banyak disebabkan oleh adanya surplus neraca non migas.

6. Neraca jasa dan unilateral transfer senantiasa mengalami defisit.

\section{Saran}

Dari kesimpulan diatas maka ada beberapa saran yang dapat diberikan:

1. Di harapkan Pemerintah dapat membuat kebijakan yang berpengaruh lansung dan konsisten terhadap peningkatan Neraca transaksi berjalan, yang nantinyaakan memperbaiki depisit Neraca transaksi berjalan.

2. Peningkatan di bidang ekspor nonmigas harus dijaga agar dapat bersaing dengan produksi lainnya, sehingga surplus neraca barang tetap terjaga.

3. Biarpun pengaruh Neraca Transaksi Berjalan terhadap pertumbuhan Ekonomi Indonesia kecil, tapi ini tidak boleh di abaikan, karena akan berdampak terhadap kenaikan inflasi. 


\section{DAFTAR PUSTAKA}

Bank Indonesia. "Neraca Pembayaran Indonesia”.

http://www.bi.go.id/web/id/Publikasi/Neraca+Pembayaran+Indonesia/. (21 April 2012, 09.21 WIB)

Bangun, Wilson. 2007. “Teori Ekonomi Mikro”. Cetakan 1. Bandung : Refika Aditama.

Basri, Faisal dan Haris Munandar. 2010. “Dasar-Dasar Ekonomi Internasional :

Pengenalan dan Aplikasi Metode Kuantitatif”. Cetakan 1. Jakarta : Prenada Media Group.

Boediono. 2001. “Seri Sinopsis Pengantar Ilmu Ekonomi No.3 : Ekonomi Internasional”. Edisi 1. Cetakan 22. Yogyakarta : BPFE.

Boediono. 2008. “Ekonomi Indonesia, Mau Kemana? (Kumpulan Esai ekonomi Boediono)”. Jakarta : Kepustakaan Populer Gramedia.

Manurung, Jonni dan Adler Haymans Manurung. 2009. “Ekonomi Keuangan dan Kebijakan Moneter”. Jakarta : Salemba Empat.

Murni, Asfia. 2009. “Ekonomika Makro”. Cetakan 2. Bandung : Refika Aditama.

Nopirin. 2009. “Ekonomi Moneter Buku II”. Edisi 1. Cetakan12. Yogyakarta : BPFE.

Nopirin. 2011. “Ekonomi Internasional”. Edisi 3. Cetakan 8. Yogyakarta : BPFE.

Prasongko, Fadjar. 1997. “Pos Jasa Transportasi Laut Dalam Neraca Transaksi Berjalan”. http://www.isjd.pdii.lipi.go.id/admin/jurnal/94971620.pdf. (29 April 2012)

Rahardja, Prathama dan Mandala Manurung. 2008. “Teori Ekonomi Makro : Suatu Pengantar (Buku Seri Teori Ekonomi)”. Edisi 4. Jakarta : LP-FEUI.

Sabirin Syahril. 2003. “Perjuangan Keluar dari Krisis”. Yogyakarta : BPFE. 